\title{
Eco-justice Pedagogy All'Italiana: Radical Italian Art in the Italian-language Classroom
}

\author{
Giuseppe Formato \\ Lesley University, US
}

\begin{abstract}
The climate crisis threatens our very existence in a myriad of urgent ways and thus merits imperative focus in pedagogic practices in general. This focus is achievable in Italian-language classrooms, where issues of global warming and climate crises are seldom mentioned, through artistic themes from Italy's rich cultural heritage of the arts. The radical art movement of Arte Povera has the potential to bring ecological concerns to the forefront through a critical cultural lens of the country. By drawing upon images of the Arte Povera movement, concepts of eco-justice and eco-pedagogy can occur through paradigms of art-based education to not only discuss the impact of the climate crisis in Italy, but also achieve Italian-language acquisition critically.
\end{abstract}

Index Terms - eco-justice, eco-pedagogy, Italian language acquisition, arts-based environmental education

\section{INTRODUCTION}

The environmental calamities of our present time will continue to have a deep impact on us now and for generations to come. Nowhere is this more apparent than in the climate crisis, with average global temperatures rising and catastrophic weather patterns due to human activity wreaking havoc on nations around the world. Italy is no exception. From flooding in Venice to droughts in the south and avalanches in the north, Italy, like all nations, is victim to human effects on nature. The severity and imperativeness of such an issue poses an existential threat to human life (Chomsky \& Pollin, 2020). However, despite the importance of culture and the overall emphasis on making subject matter relevant to learners (van Kessel, 2020), the climate crisis remains largely unaddressed in Italian-language pedagogy.

One area that potentially bridges issues of the climate crisis and Italian studies is the arts (Formato, 2018). Historically, the arts have been significant for Italy and the reason many people studied the Italian language. Examples of the arts can be seen throughout materials for learning Italian in iconic cultural images that rarely are used as a vehicle for critical thinking. Among its many complex elements, the Italian radical art movement of Arte Povera utilized natural materials, rejected consumerism, and projected an ecological and temporal narrative relative to humans and their relationship with nature. Critical thinking (Duncum, 2010) also can be born through the Italian arts by including examples of Arte Povera works to address environmental themes as a means of arts-based environmental education (Sobel, 2004) and eco-justice (Bowers, 2001). Furthermore, Arte Povera images can promote discussion, whether from the beginner level about vocabulary or at the intermediate and advanced levels using discussion and thematic units as eco-pedagogy (Gadotti, 2001).

This paper explores the concept of Arte Povera as a bridge between environment (eco-justice, eco-pedagogy, and arts-based environmental education) and Italian-language learning (critical thinking through the arts and arts in the language-learning classroom). It further introduces a practical ecological example of applying Arte Povera in the Italian studies classroom.

\section{THEORY: ENVIRONMENT}

\section{A. Eco-justice}

Environmental justice designates and describes fundamental structures of the eco-justice movement, focusing on the divergent effects of harmful waste sites and other polluting facilities in or near troubled regions with high concentrations of poor inhabitants. Because the notions and circumstances correlated with each description are complicated and multidimensional, the significance of environmental justice has shifted over time and can fluctuate significantly (Bolte et al., 2011). Such relevancies can be witnessed in an Italian context: Many are in economically depressed areas, from Italy's northern industrialized zones to its rural south, which suffers from waste management, air pollution, deforestation, forest fire, flooding, and avalanche issues due to human activity.

Environmental justice pursues the just handling and contribution of all peoples in the progress, execution, and enforcement of environmental agendas, laws, rules, and policies. Thus, as a phrase with political implications, the notion suggests justice on a distributive, technical, and preventative level. Legitimacy of this nature necessitates an unbiased allocation of the expenses of environmental consequences and of the advantages of environmental ideals across demographic and environmental dimensions. Significant importance is situated on practical justice, characterized as the magnitude to which civil choice-making procedures are affected equally. Individuals are encouraged to monitor 
and influence the choices that concern them.

The preventive theory is centered on the mindset that ecological concerns stemming from worsening ecosystems necessitate decision-making to prevent public health detriment (Lehtinen, 2009). The Italian political party, la Federazione dei Verdi, and the environmental association, Legambiente, exemplify groups that strive to make environmental culture the center of a new kind of development-one diffused with well-being and environmental quality improvement - that fights against pollution and for wise use of natural resources and balances the human-nature relationship in an Italian context.

With modern distributional questions of globalization, urbanization, and environmental deprivation (e.g., the climate crisis, deforestation, and decreasing biodiversity), the environmental justice notion has moved towards a wider generational and international understanding. Generational environmental justice implies sustainability, global environmental justice, and the present generation's accountability to guarantee a healthy and secure environment for the future. It suggests that environmental ruin in the name of present-day short-term economic profit creates injustice for future generations. As environmental reserves become ever rarer, the growing harmful ecological situations that wealthier nations inflict on emerging countries touch on an imperative for international environmental justice (RamirezAndreotta, 2019).

Pedagogical practices in teaching about Italy, a first-world country of considerable wealth —along with its language and culture - owe at least a mention of these ecological catastrophes. One cannot educate merely about a country or culture and overlook its environment. Instructors can look through the lens of Italian culture to discuss environmental issues in meaningful ways.

\section{B. Eco-pedagogy}

Eco-pedagogy originated in a Latin American educational perspective. Scholars wanted to make methodical assertions about the relationship between humanity and the Earth and to devise a learning purpose to incorporate an environmental ethos (Freire, 2004). The eco-pedagogy effort extends changes in critical pedagogy, the mass of pedagogical concepts and methods Paulo Freire inspired. It aims to advance a vigorous obligation for the shared abilities of being human and to nurture social justice throughout the world. It does so with environmental political ideas that fundamentally resist globalization of beliefs such as neoliberalism and expansionism on one hand and efforts to stimulate arrangements of critical eco-literacy on the other. Furthermore, eco-pedagogy has as an objective the understanding of socially pertinent expertise based in normative ideas such as sustainability (Gadotti, 2001).

The term eco-pedagogy mixes the two terms ecology and pedagogy. Pedagogy is a practice of instruction. It typically implies an academic subject matter or theoretic model. Eco refers to environmental conditions. In the critical theory of education, eco-pedagogy functions at a meta-level. It suggests using dialectical critiques of ecological instruction for sustainable progress as hegemonic methods of pedagogical discourse, shaped by agencies to ease the escalating worldwide ecological crisis (Jardine, 2000). Ecological instruction approaches certainly achieve much that is wanted and virtuous from an eco-pedagogical standpoint. However, eco-pedagogy also critiques the ways in which ecological teaching may deal uncritically with ideological depictions of nature that are possibly informed by racist, sexist, or classist ethics (Åhlberg et al., 2003). Moreover, eco-pedagogy has started to pose issues about how ecological instruction is fastened to corporate-funded science and social studies values. It articulates the habits in which modern society and industrial culture encourage unsustainable existences, even as it continues in research, teacher-training, and educational leadership programs within graduate schools of education. Similarly, eco-pedagogy also aims to produce conscientization around the notion of sustainable development and thus unmask it as a form of the pervasive opacity it currently upholds.

As inhabitants of the Earth, we cannot contribute to forming the world we want by allowing those who benefit from exploitation and manipulation to build that world for us. Eco-pedagogy advocates emphasize that the revolution of the political and social realms of human effort - fundamental to critical pedagogy — can happen only within a synchronized change in the environmental domain (Yang \& Hung, 2004). Environmental conversion would necessitate a drastic shift in the correlation between humanity and the powers of nature and life on Earth. Eco-pedagogy applies the critical pedagogy discourses of repression and power to the principle that all ecologies and the Earth itself need to be freed from human oppression. It suggests that real political, social, and environmental revolutions are always together and must occur within a whole-planet ecology (Kahn, 2010). Thus, eco-pedagogy's implications reach vast learning realms.

However, one largely unexplored topic is language acquisition and its relevant areas. This is particularly true of Italian-language learning and the arts. Eco-pedagogy could be perceived as a potential crossroads or platform for these subjects to raise awareness of the ecological crises at hand while staying within the realm of learning and to propagate a critical environmental consciousness in areas that traditionally are unlikely to consider such discussion, as in Italian learning and teaching.

\section{Arts-based Environmental Education}

Arts-centered environmental education combines art education and environmental education into one task. The method has two important qualities. First, it implies an environmental education that begins from an artistic methodology. Distinct from other kinds of environmental education that present space for artistic practices, arts-based environmental education reverses this situation. Art is not an additional value but the point of exit in the attempt to 
discover ways individuals can relate to their environment. Second, arts-based environmental education is one of the earliest modern-day methods of combining aesthetic training and ecological pedagogy (Mason \& Eça, 2008).

In Finland in the early 1990s, a different type of ecological instruction, in which artistic practice plays a crucial part, was theorized. Artistic practices are means of existing and of knowing one's being (Abram, 2017). Explaining our observations makes us sensitive to new information that may not come to us via language. Art proposes distinctive, often unconscious, aspects to understand and denote experiences, often at humans' sensual, perceptual, expressive, cerebral, figurative, and imaginative levels. Creating and reflecting on art improves our capability to contact the innermost levels of consciousness. Simultaneously, such endeavors nourish and steer awareness of actuality and life. They can improve and polish our views and make us vulnerable to the secrets of the things around us.

In the framework of education about nature, art has a possibility that is lacking in standard nature instruction methods. Standard instruction tends to pass on knowledge that has already been formed (Krasny \& Dillon, 2013) rather than catalyze new thinking, whereas through art, we can look at and move towards the outside realm anew. Art can strike us suddenly and occasionally inflame us. It facilitates us to examine and restore interpretations of common things and events that are so recognizable, our view of them has become mundane. In that way, using art comprises a pedagogic technique that is intrinsically pragmatic and ambiguous. Therefore, we must look more to the kind of art that challenges us than to the traditional, familiar modes the culture industry reproduces ad nauseum and that hence lack potency.

Art can expose us to chaos and to the existence of paradox, contradiction, and doubt. These qualities can be of immense importance in our present times. Arts-based environmental education is a form of understanding that seeks to improve ecological awareness and accountability by becoming more sympathetic to perception and thoughts. It uses aesthetic techniques to communicate intimate ecological experiences and reflections (Schneller, et al, 2019). Instructors can use arts-based environment education to tackle significant issues, especially issues that the ecological catastrophe provokes. The place of environment in arts-based instruction relates to both the human-made and the organic environments. It seeks to improve learners' directness and understanding and can assist them to discover new, individual ways to communicate and disclose their ecological practices (van Boeckel, 2009). For example, instructors might ask learners to go into nature and find natural objects relating to the life-cycle and then to speak about those items, forming the expression as an artwork, such as a poem or painting.

A form of Italian art that touches upon the crossroads of human influence and the environment is the radical art movement, Arte Povera. Through the arts of Italian culture, Arte Povera mirrors both human fragility and humans' deadly impact on the environment. Such a cultural platform could provide the perfect setting for those teaching Italian language to simultaneously educate on the environment through a critical art movement that has largely been overlooked.

\section{THEORY: CRITICAL THINKING}

\section{A. Critical Thinking through the Arts}

Critical thinking is a procedure that necessitates introspective abilities and assessment of concepts (Ennis, 2011). To promote these critical skills, pedagogy requires understanding learners as dynamic intellectuals and steering their meditative development through inventive approaches that stimulate autonomous beliefs and conversations (Duncum, 2010).

Currently, information has become an unbalanced element in which deviations result from the continuous international discourses new technologies create (Lyotard \& Bennington, 2010). Thus, expansion of learning skills is considered indispensable (Alter, 2011). Learning emphasis should substitute a content-instruction focus with which learners are urged to acquire knowledge (Román, 2005). This suggests a different paradigm centered on a cognitive model that promotes critical abilities to assist students' critical involvement in their environment (Gude, 2007). Thus, advancement of critical-thinking abilities has come to be a vital objective, providing learners a means for an uninterrupted learning process throughout life (Román, 2005). To cultivate more progressive and liberating criticalthought modes during lessons, nontraditional artforms should have a place in the language-learning classroom concerning culture.

Critical thinking encourages learning over time because it allows learners to identify meaningful information to resolve intricate circumstances (Hogan, 2006). Developing these abilities in learners aids their incorporation as dedicated citizens of society. It allows a critical method to distinguish and advance social consciousness and moral values (Gude, 2007). Learners must develop a critical understanding of their reality, which depends on understanding how ethical principles and beliefs are presently communicated (Grushka, 2009).

A component of that presentation is how culture is presented in Italian-language textbooks. Mostly, Italian culture has been presented through traditional modes of high art. High art has immense cultural value to world heritage and represents watershed moments in history. However, outside of those contexts, high art images reinforce stereotypical concepts of beauty and culture, void of critical thought or worldviews for language learners to acquire not only about Italian culture, but also about themselves and their relationships to the world. Arte Povera could provide the classroom platform through which to bridge Italian culture with critical thinking and better position learners to the world and the crises within it. Advancing meditative capabilities in learning is essential to help learners confront the widespread supremacy of images (Eisner, 2005) with more potent ideological content (Leavy, 2009). These abilities can aid learners 
in reading visual messages and recognizing the negotiated characteristics of new media and their relation to control (Gude, 2007).

Critical thinking is a probing endeavor that uses ambiguity as a viewpoint from which an object, situation, or idea is systematically examined (Cottrell, 2005) and purposely merges other cognitive skills (Facione, 2000). In this way, learners can perceive and distinguish others' beliefs, evaluate various views, contemplate opposing explanations, differentiate substantial approaches, and produce inferences (Ennis, 2011). To advance learners' critical thinking, instructors should stimulate thought through a cognitive model and a critical inquiry framework on matters that offer space for reasoning and discussion (Grushka, 2009). For this to occur, instructors must apply a curriculum whose foundation centers on a cognitive paradigm (Gude, 2007).

According to Hardy (Hardy, 2006), a new model established in logic seeks to question cultural beliefs and tackle numerous worldviews. For the visual arts, this model includes the aspects of analysis and discussion. In these imageinundated times, it is an important social interest to cultivate learners' personal investigation of the links among images, thoughts, feelings, and the multidimensional experiences of seeing (Grushka, 2009). Because the application of critical thinking pushes learners to investigate their own thoughts, it presents a meaningful learning experience applicable in any sphere of knowledge (Alter, 2011).

The use of a theoretical structure encourages critical thinking, suggesting that any subject has varied viewpoints (Alter, 2011). To spur active inquiry, learners should be questioned first as to what they know about an issue, exposing their opinions and promoting conversations (Hogan, 2006). By engaging a learner's subjectivity, it is feasible to question individual viewpoints about different concerns (Hickman \& Eglinton, 2009). These approaches call for the learners' participation, encouraging them to comprehend how others understand their world (Hogan, 2006). Considering the Arte Povera artists and their critical idea of society allows learners to perceive conceptions that differ from the reductive patterns of Renaissance paintings, Roman sculptures, or Fiat vehicles as cultural representations in Italianlanguage textbooks.

Visual images are key to cultivating critical thinking because they depict ideas about diverse social characteristics through various significance levels (Emmison \& Smith, 2000). Learners are engrossed in an image-flooded era where ideas are disseminated and conveyed mostly by visual means (Leavy, 2009). Visual literacy and development of a critical approach around images have thus become essential pedagogic obligations to guarantee the learners' reflective participation (Duncum, 2010). There is, nonetheless, a dearth of theoretical literature based on critical thinking within visual arts pedagogy. This scarcity suggests a reluctance to employ inquiry approaches through images (Alter, 2011) and extends to research on Italian-language pedagogy (Formato, 2018. However, Hogan (2006) suggested a shift in attention, arguing that critical thinking has emerged as an increasing interest within visual arts curricula.

The notion of visual literacy reaches beyond fine arts study. It revolves around the concept of visual culture. The presence of visual literacy in visual arts education becomes vital to nurturing critical citizens (Duncum, 2010). Visual culture includes images and matters that are crucial for learners because image is a significant part of their lives (Grushka, 2009). Learners can participate in visual culture if they are led to a critical-teaching exercise based on images. Images of Art Povera works, such as Penone's Albero porta-cedro (Fig. 1), bring attention to the fragility of the natural world; they reveal the past, truths about life and oneself, and a critical application to the current climate crisis. Thus, they position ecology, Italian language, and the learners relative to the art and everyday life.

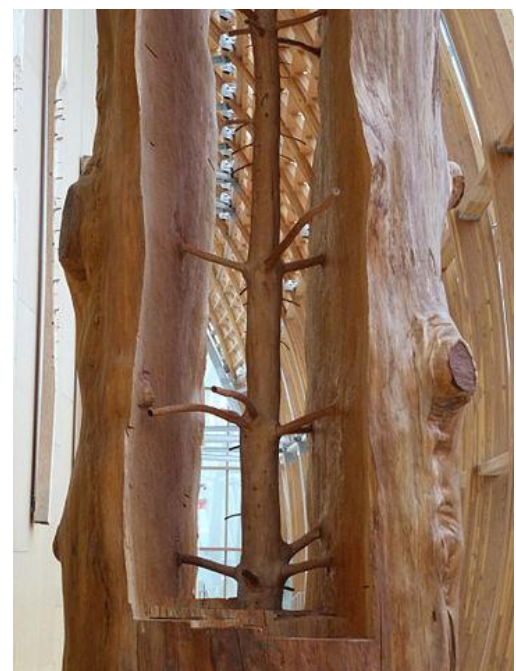

Figure 1. Albero porta-cedro (door tree-cedar); one of works Giuseppe Penone works entitled, "The Hidden Life Within," created by carving away portions of the tree and revealing the earlier stages of the trees life. Photo by Sphilbrik, Creative Commons Attribution-Share Alike 3.0 Unported license, https://creativecommons.org/ licenses/by-sa/3.0/deed.en

Conversely, more traditional art modes function as cultural reproductions void of opportunities to nurture learners in a perspective critical of them or to place meaningful value in their lives. Arte Povera's multiple layering well positions 
it in a critical inquiry framework that facilitates the reading of images (Alter, 2011). It deems the aspects around the artwork, such as its public, artist's context, topics, questions, and symbols (Hogan, 2006), to be the critical awareness of core implications and concepts included in the art. Artworks should not be approached simply by traditional deciphering tactics, in which the instructor exposes its connotations, but in a dynamic conversation guided by the instructor. A critical framework within visual arts education offers learners the chance to uncover significance using critical thinking abilities. This creates a window from which to listen to diverse voices and signifies a test of the perceptive process. With this method, learners can acknowledge issues included in the image and detect its possible underlying meanings and how the artist merged the elements into an articulate whole.

\section{B. Art in the Language-learning Classroom}

In general, responding to art can stimulate learners and lead to many language-learning activities. However, it is not simply a means for learners to describe what they see in an image. There are many other means to use art to present new vocabulary and grammatical structures in motivational and interesting ways (Abrantes de Andrade, 2006). The language instructor can actively engage learners with images in the learning process (Timuçin \& Aryoubi., 2016), for example, encouraging them to draw on their personal experiences when discussing images. Responding to art involves more senses in the learning process. Working with the arts requires one to carefully notice, analyze, and interpret different texts, images, and situations; think critically; pose problems; make decisions; and, in many cases, generate multiple solutions (Farokhi, \& Hashemi, 2012). The arts add to social and emotional growth: Incorporating art and language can develop learners' creative and critical thinking skills. They stimulate imagination and give learners opportunities to become involved in new approaches and gain positive attitudes towards learning, understanding others, and articulating their own thoughts. However, using the outdated and over(re)produced high art of the past, the learner cannot develop critical thinking skills but only regurgitate ways of perceiving what art is and the hegemonic notions it carries when reading the world.

Using the arts in the foreign-language classroom contributes to developing and enriching learners' language skills, principally, reading and oral communication. By placing art within the context of the learners' lives and allowing them to express themselves by speaking, reading, and writing about images, language instructors can build on learners' prior knowledge. In addition to the language and culture about which they are teaching, they can scaffold instruction; connect written with spoken languages; make learning relevant and meaningful; foster higher-order thinking skills; promote high levels of analysis, reasoning, and questioning; support critical and creative thinking; emphasize communicating ideas; and enhance learners' ways of observing, responding to, and representing the world around them. This connection and meaning-making is most apparent and possible in the Arte Povera movement. Arte Povera ambiguously explores modes of critique by questioning dogmatic notions of power on a spectrum from complex symbolism to the mundane, and so all learners can relate in some capacity.

When combined with reading, writing, speaking, and listening exercises, the arts can support learners to achieve high levels. Art challenges them to discover themselves, their surroundings, and consequent opportunities for complex understanding and interaction. Acquainting learners with artworks is an enjoyable feature of authentic learning (Farokhi, \& Hashemi, 2012). The arts are a fundamental feature of the human experience. They are vital to liberal social responsibility and deliver a language for forming and articulating comprehension. They can reveal potential and involve and offer diverse learners occasions to communicate what they know. Arte Povera, through its radical subject matter, could educate, provoke critical thought, and push learners to question the power structures in which they live.

The arts offer learners a new realm in which to genuinely practice the target language (Díaz, 2016). This paradigm is a learning approach that encourages and prepares individuals to deal with diversity, complexity, and transformation. It affords learners extensive knowledge of the wider society. The arts support learners to cultivate a powerful sense of social concern. Their interdisciplinary approach allows instructors freedom in how they tackle language and encourages them to develop considerate, appealing, and inventive tactics. Traditional art modes in Italian textbooks do not prepare language learners for such a transformation; they do not challenge or encourage them to think critically. Rather, these images force learners to internalize and, arguably, perpetuate passive behavior.

Traversing the field of language acquisition through Arte Povera permits exposure to an array of viewpoints and development of critical thinking. Altering how instructors outline and focus classroom activities may provide learners with opportunities to better reflect on the lessons' cultural aspects and thereby strengthen critical thinking skills (Mihaly, 2008). The arts then becomes accessible — not "something for the few," with themes that are distant for learners without art-history backgrounds. Using the foreign language within the realm of the arts brings learners directly to other disciplines that are compatible with their own vocabulary for identifying and describing objects. The target language is used to discuss art and to extract learners' opinions, thoughts, and feelings. Arte Povera as a movement provides many striking images with themes that elicit intense discussion and opinion. Learners of Italian would otherwise not be exposed to such rich, challenging, and varied viewpoints within the context of Italian culture.

Resources created for the language learner traditionally prioritized language over culture (Moeller \& Fatlin Osborn, 2014). If language learning is the lone goal of instruction, then such structured texts provide an obvious choice. However, if the objective is about arriving at other cultures through rising views as well as language, then texts and materials that are more critical are necessary (Randolph \& Johnson, 2016). Instructors who deliver a false analysis framework risk propagating labels that do not improve students' cultural competencies (Garrett-Rucks, 2016). In this 
sense, Arte Povera in the Italian-language classroom becomes a means to end such propagation by introducing a critical way of viewing and interpreting the world through Italian culture. When instructors neglect such a critical viewpoint, learners are left with predetermined cultural understandings that were not established critically. That is, antiquated texts and pedagogical methods hinder learners' critical assessments of different cultures to understand the world themselves.

By inserting Arte Povera into the curriculum, language learning can become a communication model relative to the learners' increasing capabilities. The critical divergence between a language and a discourse curriculum fosters an understanding that learners at all stages should be allowed and guided to examine critically. Communicative language instruction must underscore task provision for the practical language. Differentiating between first- and second-order tasks (Breidbach, 2011) permits distinction between nonreflexive tasks in a conventional language curriculum and cases for a more reflexive structure open to discussion of subject matter, purpose, and form.

Foreign-language resources for critical pedagogy must promote both social and language-aptitude growth (Rashidi \& Safari, 2011). Learners acquire methods to critique the status quo and take transformative measures to eliminate inequities while they grasp the target language (Reagan \& Osborn, 2020). A critical curriculum prepares learners to read the world (Freire \& Macedo, 1987). Similarly, language-learning materials must help learners to go beyond the written word to reach awareness and act to change the world. Arte Povera does this by exposing learning to critical interpretation, which challenges learners to reconsider their own and the Italian culture and their relation to temporality by considering provocative images and subject matter. Language acquisition abilities are useful only in relation to transformative action (Rashidi \& Safari, 2011).

Foreign language can become a means to realize sociopolitical issues and cultural morals (Reagan \& Osborn, 2002). In the Arte Povera example, the use of images in the classroom is not weighed on empty samples of art for the sake of filling pedagogical space with masterpieces. Arte Povera not only introduces learners to a cultural art movement, but also provides an opportunity to discuss, describe, and learn in Italian through a subject matter that can extend to current social issues and relationships with the environment in ways that traditional art modes cannot. Additionally, Arte Povera's ambiguous nature, perspective, and interpretation of abstract and modern draw on learners' knowledge, experiences, and visions more flexibly. Traditional art, such as Renaissance modes, allows only passivity without critical theory. Thus, Arte Povera could be a means for learners to access their language abilities to critically uncover and transform circumstances in their own and in the target-language cultures (Degener, 2001).

Basing his views in a Marxist class assessment, Freire (2000) postulated that instruction's aim was to organize learners to criticize their social circumstances and to emphasize agency to self-govern individually and as a group. Freire's conception of praxis, the mix of critical contemplation and work in service of an egalitarian and emancipatory development, revealed his belief that education is inextricable from moral and political concerns. The reconceptualist movement integrated critical pedagogy (Giroux et al., 2001) and linked learning, politics, and the social situation. This incorporation boosted the need for critical education, a move that challenged the sociopolitical shift to privatization, market-based rationalities, and austerity actions under Ronald Regan in the United States and Margaret Thatcher in the United Kingdom. With its vision of teaching as an ethical, political, and rational practice, critical pedagogy-like Arte Povera - disturbs common sense and underlines the struggle for agency.

Lasting instruction is consequently concerned with what the environment, its organizations, and its relationships teach. Cultural transmission and intake are pedagogical; instruction is heightened and disseminated more so than is formal education. The pedagogic influence of culture disputes the notion that traditional schooling is the only location where learning takes place (Giroux, 2001). It incorporates this instruction with the main concerns of a capitalist culture - the concept of a few in control-and connects with and instructs the many. This incorporation develops and muddles the field of culture and demonstrates how cultural practices, societies, and people impact one another.

\section{Discussion: An ECOlogiCAl ApPliCAtion of ARTe Povera to the Italian-Language Classroom}

Traditional language pedagogy is devoted to a standards-and-testing culture that veers towards disregarding particularities and homogenizing learners' experiences. Communities, both human and natural, are not essential parts of its curriculum (Gruenewald, 2008). Thus, contemporary art and visual culture are seldom considerable parts of the curriculum (Wilson, 2003). The concerns of gender, power, privilege, politics, and social change that are linked to visual culture, such as through Arte Povera, are sometimes problematic in the traditional classroom (Freedman, 2003). Arte Povera may not feel as comfortable or passive as mainstream cultural subjects in the pedagogy; it asks learners to question and think critically about the Italian culture, as well as their own, in ways that other Italian cultural images, such as cathedrals, masterwork paintings, or sports cars, glorify. Instruction that disregards critical modes of art, as do many texts used in Italian-language curricula, robs learners of the opportunity to become aware in emergent systems of artistic discourse. It denies them information about social and ecological justice matters and delays their cultivation of social and ecological integrity.

The crossroads of mainstream didactic principles and taken-for-granted methods among instructors often leaves unexamined the critical issues of ecology (e.g., the climate crisis) that alter our way of life. It especially affects the future of current learners, irrespective of culture, language, or country (Graham, 2004). Such an absence of critical issues ignores the possibility of the arts to instruct and inspire active engagement with ecological matters. Arte Povera artists provoke issues about nature, society, and culture that reveal the intricate composition of humans' rapport with 
nature. Artworks from this movement often have ties to the peculiarities of sites and are devoted to the network of relations that comprise local culture and ecology. Their job makes ecological relations understandable in a manner that can be a means for consciousness and subsequent transformation. Critical pedagogy, coupled with eco-justice, generates a thorough theoretical structure that merges the ecological emphasis of place-based instruction with the social emphasis of critical theory (Gruenewald, 2008) into the Italian-language classroom. Giuseppe Penone's The Hidden Life Within provides an example applied to ecology. Within this work, Penone carefully removed rings of growth from a fir tree to reveal its former young shape hidden beneath decades of growth. He arrived at these forms by carving the tree trunk but leaving the knots in place until they emerged as limbs, revealing the sapling within. The viewer considers the future of the natural world as a dead tree presented within a living one.

In an Italian-language classroom, for example, beginner-level vocabulary and descriptive adjectives related to nature, the climate crisis, and the artwork can be presented using Arte Povera as a vehicle. At intermediate and higher-level classes, whole conversations about climate change could be based around these works through communicative discussion: The rising sea level in Venice, forest fires and drought in southern Italy, and some of the worst air pollution in urban areas on the European continent could be discussed with more advanced grammar structures taught in the cultural context.

Penone's work blurs the boundaries between environmental art and ecological concern in ways that are restorative, critical, and interdisciplinary when considered in the Italian language-learning context. His work, like others of the Arte Povera movement, is critical in the ways it re-envisions the artmaking purposes and the artist's role. Involving learners of Italian in this kind of study of Italian culture through language connects language acquisition to important issues within the local context of learners' lives and encourages them to consider the convergence of politics, power, and culture where they reside in an Italian-language environment.

Giovanni Anselmo's Eating Structure consists of a small block of granite connected to a larger block by means of a head of lettuce and wire. If the lettuce dries, then the smaller block falls. Thus, the sculpture must be "fed" new lettuces regularly to uphold its form. It implies the mastery of nature over human creation, characterized by the capability of tree roots to destabilize foundations or stonework over time. The work suggests the dominance of nature; it is environmentalist in its insistence on carefully tending the sculpture's plant-based aspects. Its concern with balance and gravity also echoes in its use of materials as mundane as a head of lettuce, which is typical of Arte Povera's evocation of poor and rural life.

However, exercises and thematic units such as these simply do not exist in Italian-language materials. Italianlanguage instruction ignores the ecological in favor of the rationality of standardized, traditional art images. There is a pervasive responsibility to train learners to achieve in a market that is individualistic, unsustainable, and undemocratic. Instruction that accentuates testing regularly disregards social and ecological methods that are repressive and ecologically devastating (Gruenewald, 2004). A sense of caring for place is gone, and different cultural views towards nature that are more ecologically receptive are disregarded (Bowers, 2001).

Arte Povera in the Italian-language classroom is a reaction to standard pedagogy that disregards ecological areas and, through an Italian lens, places consumerism, high fashion, and luxury automobiles on a pedestal. It draws on radical practices of multidisciplinary, authentic learning that seek to expand learning beyond the classroom norms. As critical pedagogy connected to nature, Arte Povera intends to bolster learners' relations to others and the land and to defeat the isolation and separation often correlated with modern society (Smith, 2002). In an Italian class, Arte Povera's emphasis on the natural world can refocus essential importance on the network of connections among human and natural communities (Berry, 2005). It can consider nature for substance and context and has sustainability as an objective (Theobald \& Curtiss, 2002).

Critical pedagogy through Arte Povera in the Italian-language classroom is important because it mixes ecological with cultural and social critique. Critical ecological assessment through the arts illustrates vital relations between cultural structures and ecological systems and confirms that social and eco-justice are intricately linked (Bullard, 2001). Arte Povera gives ethical sensitivities to the nonhuman world and investigates interactions among ecological, social, cultural, and political issues in Italy and beyond. Merging Arte Povera with critical pedagogy creates a tactic described by distorted frontiers between art, social critique, scientific analysis, and activism. Arte Povera artists' works interrupt beliefs about our relations with nature and suggest that art might include interdisciplinary networks (Graham, 2007).

Arte Povera as critical pedagogy instruction seeks to cultivate learners' capabilities to critically assess the images and objects of art and visual culture by pondering topics of power and politics. Its viewers can make assertions that influence social awareness and potentially support transformation. The study of the arts also is linked to continuing social struggles, in that it is viewed as a location for ideological struggle (Darts, 2004). The transformative weight of Arte Povera in Italian instruction coincides with the concerns for social and eco-justice that distinguish critical pedagogy. Arte Povera helps the viewer see the world from new perspectives. The arts, and Arte Povera in particular, provide prospects for understanding alternate methods of transcending and being and disrupt thoughtlessness, complacencies, and certitudes (Greene, 2018). Learners can eliminate or modify their cultural principles and taken-forgranted mindsets. The importance of this, in the framework of a critical Italian-language pedagogy, is that ecological crises can be related to assumed capitalist representations of competition, progress, consumption, and domination over nature (Bowers, 2001). 


\section{CONCLUSION}

Using Arte Povera in the Italian classroom can be a valuable source and moment of critical thinking that bridges the quintessential Italian culture of the visual arts traditions with the climate crises and other ecological issues. No longer can learning space be void of critical discussion or overlook opportunities that bring about ideas on these urgent issues (van Kessel, 2020). Rather, through the notions of ecological justice and respect for the Earth and all who live there, a different eco-pedagogy based on a critical pedagogic framework can be considered in language classrooms (Levy \& Kennedy, 2005). The radical art movement of Arte Povera does not require the language instructor to look beyond Italian culture to utilize a cultural means to address these ecological issues. Arte Povera allows instructors to present the issues in a way that forces a rethinking of what Italian culture is, what Italian art is, how the classroom time should be spent, and how to learn language in a way that addresses culture as well as existential threats to society (Chomsky \& Pollin, 2020) while simultaneously acquiring Italian. Rather than perpetuating outdated and hegemonic notions of Italian art or teaching Italian through overuse of the same images of the gilded and marbled past, a critical, arts-based education could revitalize the platform to acquire Italian, learn about revolutionary art forms and history, and approach ecological crises. Considering eco-justice through arts education in language acquisition via Arte Povera is more necessary than ever as the climate crisis becomes more threatening and a greater part of the learners' reality.

\section{REFERENCES}

[1] Abram, D. (2017). The spell of the sensuous: Perception and language in a more-than-human world. New York: Vintage Books

[2] Abrantes de Andrade, E. M. (2006). Improving how listening skills are taught in the EFL classroom. Master's thesis, Universedade de Cabo Verde.

[3] Åhlberg, M., L. Turja \& J. Robinson. (2003). Educational research and development to promote sustainable development in the city of Helsinki: Helping the accessible Helsinki Programme 2001-2011 to achieve its goals. International Journal of Environment and Sustainable Development 2, 197-209. doi:10.1504/IJESD.2003.003321.

[4] Alter, F. (2011). Exploring visual arts pedagogies that support critical and creative thinking. Australian Art Education 34, 1029.

[5] Román, M. (2005). Sociedad del conocimiento y refundación de la escuela desde el aula. Madrid: EOS.

[6] Berry, W. (2005). The way of ignorance and other essays by Wendell Berry. Boston, MA: Showmaker \& Hoard.

[7] Bolte, G., A. Pauli \& C. Hornberg. (2011). Environmental justice: Social disparities in environmental exposures and health; overview. In J. O. Nriagu (ed.), Encyclopedia of environmental health (vol. 2). Burlington, VT: Elsevier, 459-470.

[8] Bowers, C. A. (2001). Educating for eco-justice and community. Athens: University of Georgia Press.

[9] Breidbach, S. (2011). Teaching for "strong voices": Reconstructing the reflexive dimension in communicative language teaching. In S. Breidbach, D. Elsner \& A. Young (eds.), Language awareness in teacher education. Frankfurt: Peter Lang, 97113.

[10] Bullard, R. D. (2001). Environmental justice in the 21st century: Race still matters. Phylon 49, 151-171. doi:10.2307/3132626.

[11] Chomsky, N. \& R. Pollin. (2020). The climate crisis and the global green new deal: The political economy of saving the planet. London: Verso Books.

[12] Cottrell, S. (2005). Critical thinking skills. Basingstoke, UK: Palgrave Macmillan.

[13] Darts, D. (2004). Visual culture jam: Art, pedagogy, and creative resistance. Studies in Art Education 45, $313-327$. doi:10.1080/00393541.2004.11651778.

[14] Degener, S. C. (2001). Making sense of critical pedagogy in adult literacy education. In J. Comings, B. Garner \& C. Smith (eds.), Annual review of adult learning and literacy (vol. 2). San Francisco: Jossey-Bass, 26-62.

[15] Díaz, E. M. (2016). Expanding the Spanish classroom: The "art" in liberal arts. Hispania 99, $436-449$. doi:10.1353/hpn.2016.0070

[16] Duncum, P. (2010). Seven principles for visual culture education. Art Education 63, 6-10.

[17] Eisner, E. (2005). Opening a shuttered window: An introduction to a special section on the arts and the intellect. Kappan 87, 14-18. doi:10.1177\%2F003172170508700104.

[18] Emmison, M. \& P. Smith. (2000). Researching the visual: Images, objects, contexts and interactions in social and cultural inquiry. London: Sage.

[19] Ennis, R. H. (2011). Critical thinking: Reflection and perspective, part 1. Inquiry: Critical Thinking across the Disciplines 26(2), 4-18.

[20] Facione, P. A. (2000). The disposition toward critical thinking: Its character, measurement, and relationship to critical thinking skill. Informal Logic 20, 61-84.

[21] Farokhi, M. \& M. Hashemi (2012). The impact/s of using art in English language learning classes. Procedia: Social and Behavioral Sciences 31, 923-926. doi:10.1016/j.sbspro.2011.12.170.

[22] Formato, G. (2018). Instilling critical pedagogy in the Italian language classroom. Journal of Language Teaching and Research 9, 1117-1126. doi:10.17507/jltr.0906.01

[23] Freire, P. (2004). Pedagogy of indignation. Boulder, CO: Paradigm.

[24] Freire, P. \& D. Macedo (1987). Literacy: Reading the word and the world. London: Routledge.

[25] Freire, P. (2000). Pedagogy of the oppressed (30th ann. ed.). New York: Continuum.

[26] Freedman, K. (2003). Teaching visual culture. New York: Teachers College Press.

[27] Gadotti, M. (2001). Pedagogy of the Earth. São Paulo: Peirópolis.

[28] Garrett-Rucks, P. (2016). Intercultural competence in instructed language learning: Bridging theory and practice. Charlotte, NC: Information Age.

[29] Greene, M. (2018). Landscapes of learning. New York: Teachers College Press. 
[30] Levy, M. \& C. Kennedy. (2005). Learning Italian via mobile SMS. In A. Kukulska-Hulme \& J. Traxler (eds.), Mobile learning: A handbook for educators and trainers. London: Routledge, 76-83.

[31] Giroux, H. A., P. Freire \& S. Aronowitz. (2001). Theory and resistance in education: Towards a pedagogy for the opposition. Westport, CT: Greenwood.

[32] Giroux, H. A. (2001). Theory and resistance in education: Towards a pedagogy for the opposition (rev. ed.). Westport, CT: Bergin \& Garvey.

[33] Graham, M. A. (2007). Art, ecology, and art education: Locating art education in a critical placed-based pedagogy. Studies in Art Education 48, 375-391. doi:10.1080/00393541.2007.11650115.

[34] Gruenewald, D. A. (2004). A Foucaldian analysis of environmental education: Toward the socioecological challenge of the earth charter. Curriculum Inquiry 34, 71-107. doi:10.1111/j.1467-873X.2004.00281.x.

[35] Gruenewald, D. A. (2008). The best of both worlds: A critical pedagogy of place. Environmental Education Researcher 14, 308-324. doi:10.1080/13504620802193572.

[36] Grushka, K. (2009). Meaning and identities: A visual performative pedagogy for socio-cultural learning. Curriculum Journal 20, 237-251. doi:10.1080/09585170903195860.

[37] Gude, O. (2007). Principles of possibility: Considerations for a 21st century art and culture curriculum. Art Education 60, 6-17. doi:10.1080/00043125.2007.11651621.

[38] Hardy, T. (2006). Art education in a postmodern world: Readings in art and design education series. Bristol, UK: Intellect.

[39] Hickman, R. \& K. Eglinton (2009). Exploring the ways in which youth engage with visual material culture in their everyday lives: A framework for inquiry. Australian Art Education 32, 4-16.

[40] Hogan, M. (2006). Implementing critical inquiry in arts responding classes: Studies of teaching strategies whilst studying contemporary art works. Master's thesis, University of Melbourne.

[41] Jardine, D. W. (2000). Under the tough old stars: Ecopedagogical essays. Brandon, VT: Solomon Press.

[42] Kahn, R. (2010). Critical pedagogy, ecoliteracy and planetary crisis: The movement. New York: Peter Lang.

[43] Krasny, M. E. \& J. Dillon. (2013). Trading zones in environmental education: Creating transdisciplinary dialogue. New York: Peter Lang.

[44] Lehtinen, A.-A. (2009). Environmental justice. In R. Kitchin \& N. Thrift (eds.), International encyclopedia of human geography. Oxford: Elsevier, 535-539.

[45] Leavy, P. (2009). Method meets art: Arts-based research practice. New York: Guilford Press.

[46] Lyotard, J.-F. \& G. Bennington. (2010). The postmodern condition: A report on knowledge. Minneapolis: University of Minnesota Press.

[47] Mason, R. \& T. T. P. Eça. (2008). International dialogues about visual culture, education and art. Bristol, UK: Intellect

[48] Mihaly, D. (2008). The stealth approach to critical thinking in beginning Spanish classes. In A. Moeller, J. Theiler \& S. Betta (eds.), Turning today's students into tomorrow's stars: 2008 report of the Central States Conference on Teaching Foreign Languages. Milwaukee: CSCTF, 37-54.

[49] Moeller, A. \& S. R. Fatlin Osborn. (2014). A pragmatist perspective on building intercultural communicative competency: From theory to classroom practice. Foreign Language Annals 47, 669-683. doi:0.1111/flan.12115.

[50] Ramirez-Andreotta, M. (2019). Environmental justice. In M. L. Brusseau, I. L. Pepper \& C. P. Gerba, Environmental and pollution science (3rd ed.). London: Academic Press, 573-583.

[51] Randolph, L. J., Jr. \& S. M. Johnson. (2016). Bringing culture instruction and social justice together in the language classroom. Video webinar, American Council on the Teaching of Foreign Languages. https://www.actfl.org/ (accessed 16/9/2020).

[52] Rashidi, N. \& F. Safari (2011). A model for EFL materials development within the framework of critical pedagogy (CP). English Language Teaching 4, 250-259.

[53] Reagan, T. \& T. Osborn (2002). The foreign language educator in society: Toward a critical pedagogy. Mahway, NJ: Lawrence Erlbaum Associates.

[54] Schneller, A. J., L. M. Harrison, J. S. Adelman \& S. M. Post. (2019). Outcomes of art-based environmental education in the Hudson River Watershed. Applied Environmental Education \& Communication. doi:10.1080/1533015X.2019.1617805.

[55] Smith, G. (2002). Place-based education: Learning to be where we are. Kappan 83, 584-595. doi: $10.1177 \% 2 F 003172170208300806$.

[56] Sobel, D. (2004). Place-based education: Connecting classrooms and communities. Barrington, MA: Orion Society.

[57] Theobald, P. \& J. Curtiss. (2002). Communities as curricula. Forum for Applied Research and Public Policy 15, $106-112$.

[58] Timuçin, M. \& H. Aryoubi. (2016). Integrating arts in EFL curricula: A focus on language listening skills. International Journal of Languages' Education and Teaching 4, 233-256.

[59] van Boeckel, J. (2009). Arts-based environmental education and the ecological crisis: Between opening the senses and coping with psychic numbing. In B. Drillsma-Milgrom \& L. Kirstina (eds.), Metamorphoses in children's literature and culture. Turku, Finland: Enostone, 145-164.

[60] van Kessel, C. (2020). Teaching the climate crisis: Existential considerations. Journal of Curriculum Studies Research 2, 129 145. doi:10.46303/jcsr.02.01.8.

[61] Wilson, B. (2003). Of diagrams and rhizomes: Visual culture, contemporary art, and the impossibility of mapping the content of art education. Studies in Art Education 44, 214-229. doi:10.1080/00393541.2003.11651740.

[62] Yang, S. K. \& R. Hung. (2004). Towards construction of an ecopedagogy based on the philosophy of ecocentrism. Journal of Taiwan Normal University 49(2), 1-18

Giuseppe Formato, $\mathrm{PhD}$, is a senior lecturer at Lesley University and teaches courses in language and film. He is also a postdoctoral fellow at ISCTE-Lisbon University Institute and a visiting researcher at its Centre for Research and Studies in Sociology. 